\title{
SEMIAUTOMATIC AND FULLY FUNCTIONAL ELECTROCHEMICAL MICROANALYZER BO-05 SUITABLE FOR SCIENTIFIC, DIDACTIC AND ANALYTICAL APPLICATIONS: THE USE IN THE POTENTIOMETRIC ANALYSIS OF DRUGS
}

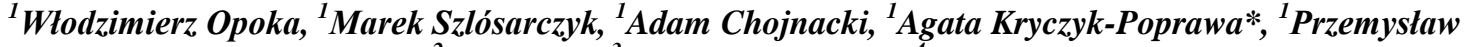 \\ Talik, ${ }^{2}$ Jozsef Gal, ${ }^{3}$ Bożena Muszyńska, ${ }^{4}$ Bogustaw Baś \\ ${ }^{1}$ Department of Inorganic and Analytical Chemistry, Pharmaceutical Faculty, Medical College, Jagiellonian University, 9 Medyczna \\ St., 30-688 Kraków, Poland, \\ ${ }^{2}$ Faculty of Engineering University of Szeged, Mars tér 7, 6724 Szeged, Hungary, \\ ${ }^{3}$ Department of Pharmaceutical Botany, Pharmaceutical Faculty, Medical College, Jagiellonian University, 9 Medyczna St., 30-688 \\ Kraków, Poland, \\ ${ }^{4}$ AGH University of Science and Technology, Faculty of Materials Science and Ceramics, al. Mickiewicza 30, 30-059 Kraków, \\ Poland, \\ e-mail: agata.kryczyk@uj.edu.pl
}

Received: February 11, $2021 \cdot$ Accepted: February 24, 2021

\begin{abstract}
This article presents the potentiometric method of determination of chlorides using the original BO-05 electrochemical microanalyzer. The quantification of chlorides is one of the frequently performed methods, both in the indirect determination of active pharmaceutical ingredients (API) and impurities in pharmaceutical raw materials, pharmacopoeial substances or pharmaceutical formulations as well. Successfully validated method was used to the analysis of chlorides in the preparations containing verapamil hydrochloride in form of tablets Staveran ${ }^{\circledR}$ and Verapamil $^{\circledR}$. The mean content of the studied API calculated to one tablet was close to the declared and equal to $123.6 \pm 1.5 \mathrm{mg}$ and $122.6 \pm 1.1 \mathrm{mg}$, respectively. The presence of excipients have no significant impact on the final results. Thus shown that the electrochemical microanalyzer BO-05 is suitable for scientific, didactic and analytical applications.
\end{abstract}

Keywords: potentiometric methods, potentiometric titration, electrochemical microanalyzer, verapamil hydrochloride

\section{INTRODUCTION}

The BO-05 microanalyzer combines both the functions of a potentiometer with high internal resistance and a potentiostat. The innovative BO-05 analyzer was constructed with the use of electronic devices and programmed appropriately for analytical purposes, using various types of sensors and microsensors, both scientific and educational. The analysis includes such methods as: potentiometry, stripping potentiometry, linear sweep voltammetry, anodic stripping voltammetry or chronoamperometry. The constructed microanalyzer is connected to a computer via the R-232 port which allows the manual and automatic control. Both the software and the equipment used minimize the amount of data necessary for the correct performance of the analysis and enabling quick online presentation of results. Direct connection with MS Office Excel enables immediate analysis of the obtained results and significantly improves the necessary calculations.

Verapamil (2-(3,4-dimethoxyphenyl)-5-[2-(3,4-dimethoxyphenyl)ethyl-methylamino]-2-propan-2ylpentanenitrile; hydrochloride - Fig. 1) is currently one of the most widely used anti-arrhythmic drugs from the group of calcium channel blockers [1-4]. In pharmaceutical preparations, such as Staveran ${ }^{\circledR}$ and Verapamil $^{\circledR}$, it is used in doses of 40,80 or $120 \mathrm{mg}$. 
<smiles>COc1ccc(CCN(C)CCC[C@](C#N)(c2ccc(OC)c(OC)c2)C(C)C)cc1OC</smiles><smiles>COc1ccc(CCN(C)CCC[C@](C#N)(c2ccc(OC)c(OC)c2)C(C)C)cc1OC</smiles>

Figure1. The chemical structure of verapamil

Verapamil is determined by various analytical techniques e.g. chromatographic [5-8], spectrophotometric [1], spectrofluorometric [9,10], voltamperometric [11], amperometric [12]. Verapamil with hydrochloride, in the studied pharmaceutical preparations, is present in a molar ratio of 1:1 [7]. Therefore, it is possible to determine the content of verapamil based on the amount of chlorides in this preparation. To determine the chloride content, a precipitimetric method with a potentiometric end point detection was used. Standard solutions containing chlorides were titrated with silver nitrate $(\mathrm{V})$ solution in the platinum electrode system as indicator and silver chloride electrode as reference. In this work, an attempt was made to indirectly determine the content of verapamil in the studied drugs, based on the analysis of the content of an equivalent amount of chlorides.

\section{MATERIALS AND METHODS}

\subsection{Materials}

Used in the research potassium nitrate $\left(\mathrm{KNO}_{3}\right)$ and concentrated nitric acid $\left(\mathrm{HNO}_{3}\right)$ were both Suprapur Merck. Water (quadruple-distilled) with a conductivity of less than $1 \mu \mathrm{S} / \mathrm{cm}$ was obtained using an S297A2 distillation apparatus (ChemLand, Stargard Szczecin, Poland). The Staveran ${ }^{\circledR}$ (Medana Pharma SA) and Verapamil ${ }^{\circledR}$ (Mylan Pharmaceuticals Inc.) drugs were obtained in a local pharmacy. 


\section{Analecta Technica Szegedinensia}

\subsection{Instrumentation}

All potentiometric measurements were performed using a homemade BO-05 analyser (Fig. 2).

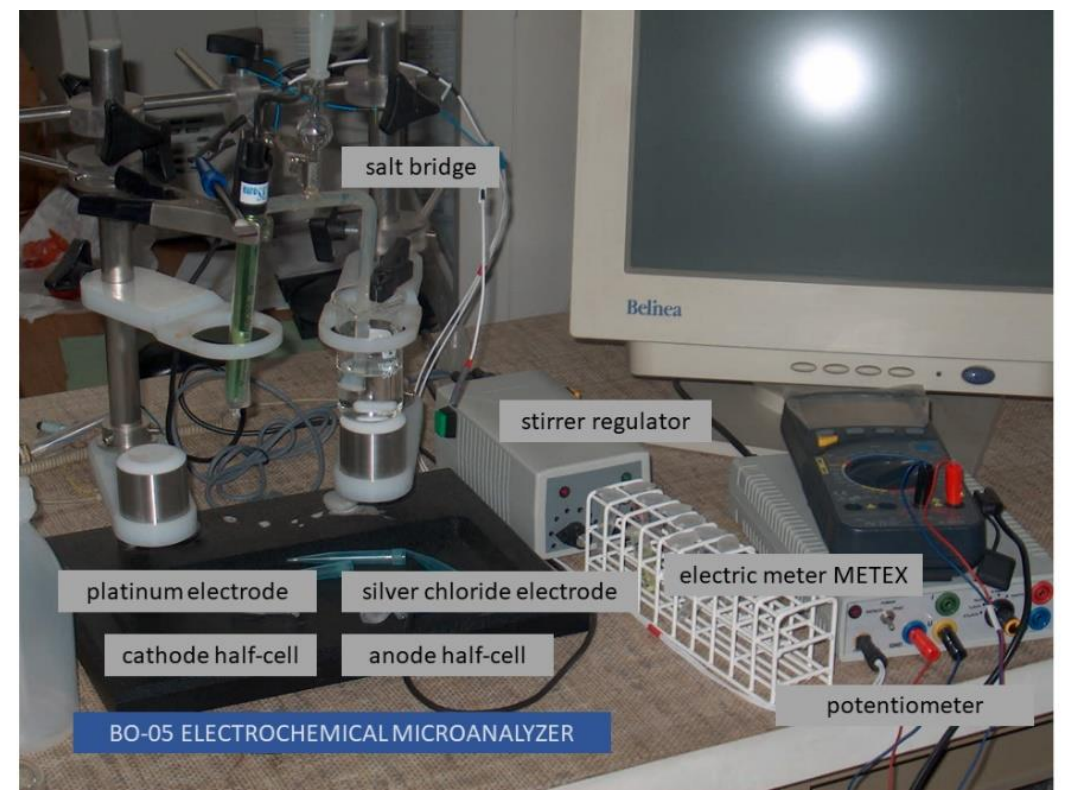

Figure 2. The image of the Electrochemical Microanalyser $\mathrm{BO}-05$

The analyzer has been constructed using electronic components and programmed to be suitable for scientific, didactic and analytical applications using various electrochemical sensors and micro-sensors. The techniques accessible in the BO-05 analyzer include: various potentiometric methods, potentiometric stripping analysis, linear sweep voltammetry, anodic stripping voltammetry and chronoamperommetry. The input impedance for potentiometer was greater than $10^{15} \mathrm{ohms}$ and the input current was lower than $0.1 \mathrm{pA}$. For driving potentiostat circuitry, potential range is $\pm 8 \mathrm{~V}, 2 \mathrm{mV}$ potential resolution and $10 \mathrm{~ms}$ timing template are typical working parameters. The work of the analyzer is controlled manually and communicated with the computer by the RS-232 port. The applied hardware and software arrangement minimizes number of necessary data interchange transactions during measurement procedure and enables a true on-line presentation of measurement results.

The presented system for electrochemical analyses consists of three separate hardware modules: the analyzer BO-05, a desktop or mobile computer and electrodes stand.

The block diagram of BO-05 analyzer is shown on Fig. 3. 


\section{Analecta Technica Szegedinensia}

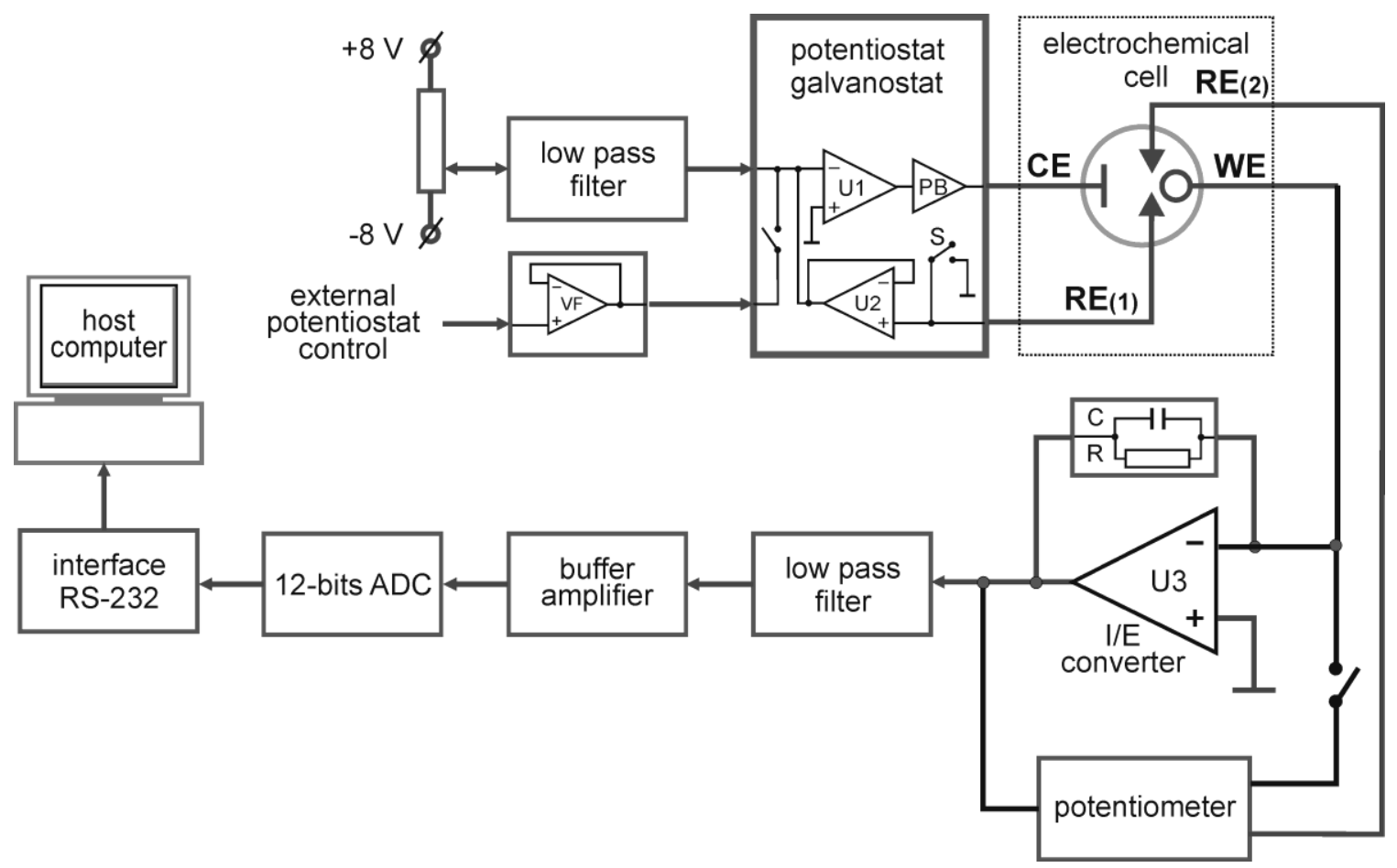

Figure 3. Block diagram of analyzer type BO-05. WE -working electrode; RE -reference electrode; CE -counter/auxiliary electrode; PB -power booster; $V F$-voltage follower; $S$-switch of potentiostat mode (two or three electrode)

The analyzer consists of the following functional subassemblies (modules): a) power supply, b) communication interface, c) analog to digital converters, d) potentiometer, e) potentiostat and current-tovoltage converter. Once measurement procedure is in progress the only data transmitted to host computer are results of analog to digital conversions and other data necessary to presentation of results in a form of measurement curve. The potential waveform, through low pass filter drives inverting input of summing, first amplifier of the potentiostat (U1). The output signal of the summing amplifier is than current-boosted (PB) and flows to counter/auxiliary electrode (CE) of electrochemical cell. Reference electrode (RE) and high input impedance amplifier (U2) close feedback loop of the potentiostat providing summing current without disturbing the potential of the reference electrode. Configuration switch (S) enables selection of potentiostat mode: two or three electrode. Feedback loop amplifier (U2) and reference electrode (RE) are used in three-electrode configuration only, while in two-electrode configuration, seldom used, counter electrode serves as quasi-reference electrode. The current that flows through working electrode (WE) as an effect of processes inside the electrochemical cell is further amplified in I/E converter (U3). Value of R and $\mathrm{C}$ elements in a feedback loop of I/E converter determine the instrument's sensitivity and are selected prior to measurement execution by configuration reed relay connectors. There are 5 full-scale ranges available from $10 \mathrm{nA}$ to $10 \mathrm{~mA}$, and they allow for precision adjust of the instrument's sensitivity with regard to the monitored process. An output low-pass filter is used to suppress high frequency noise generated (in analog circuitry, cell and cables) on ADC input. High performance amplifiers (AD744 by Analog Devices) are used in the analyzer's analog circuitry with exception of current booster (OPA627 by Burr Brown). 


\section{Analecta Technica Szegedinensia}

\subsection{Methods}

Before starting the analysis, 20 tablets of the each preparation under study were weighed and ground in a porcelain mortar. The obtained powder was partially accurately weighed and transferred quantitatively to a $50 \mathrm{~mL}$ volumetric flask and filled to the mark with quadruple-distilled water. The resulting solution was filtered.

$5 \mathrm{~mL}$ of $1 \mathrm{M} \mathrm{KNO}_{3}$ was added to the first of the measuring cell, and an appropriate amount of the sample solution, $20 \mu \mathrm{l}$ of concentrated $\mathrm{HNO}_{3}$ and quadruple-distilled water were added to the second one measuring cell. Half-cells were connected with each other using an electrolytic key filled with $10 \%$ agar gel and $0.1 \mathrm{M} \mathrm{KNO}_{3} .0 .001 \mathrm{M} \mathrm{AgNO}_{3}$ solution was added in equal portions to the measuring cell with the API under study at $10 \mathrm{~s}$ intervals. The SEM measurement of the measuring cell was recorded at $10 \mathrm{~s}$ intervals. Thus, 15 to 25 readings were obtained depending on the concentration of verapamil in the sample. The titration end point was determined automatically by the Hahn's method. The analyzes were performed in the Pt platinum electrode and $\mathrm{Ag} / \mathrm{AgCl}$ silver chloride electrode.

The obtained results were developed with the use of a proprietary program Metex-bis, written in a Visual Basic. The statistical analysis was performed using the Statistica 10.0 program and the Microsoft Excel 2010 spreadsheet.

\section{RESULTS}

\subsection{Method validation}

\subsubsection{Precision}

To check the precision of the method at one level, stock solution containing chlorides was prepared. Then, $100 \mu \mathrm{L}$ of this solution with $50 \mu \mathrm{L}$ of concentrated nitric acid were added into the measuring cell and filled with quadruple-distilled water up to $5 \mathrm{~mL}$. The chlorides content in analyzed samples calculated to verapamil hydrochloride was $0.8 \mu \mathrm{g}-$ Tab. 1. Fig. 4 shows examples of titration curves.

Table 1. Results from method validation. Precision.

\begin{tabular}{|c|c|c|c|c|c|}
\hline No & sample $[\mu \mathrm{g}]$ & $\begin{array}{c}\text { calculated } \\
\text { amount }[\mu \mathrm{g}]\end{array}$ & $\overline{\mathbf{x}}$ & SD & $\%$ RSD \\
\hline 1 & \multirow{9}{*}{0.800} & 0.827 & \multirow{9}{*}{0.810} & \multirow{9}{*}{0.021} & \multirow{9}{*}{2.59} \\
\hline 2 & & 0.843 & & & \\
\hline 3 & & 0.809 & & & \\
\hline 4 & & 0.779 & & & \\
\hline 5 & & 0.816 & & & \\
\hline 6 & & 0.816 & & & \\
\hline 7 & & 0.786 & & & \\
\hline 8 & & 0.793 & & & \\
\hline 9 & & 0.822 & & & \\
\hline
\end{tabular}




\section{Analecta Technica Szegedinensia}

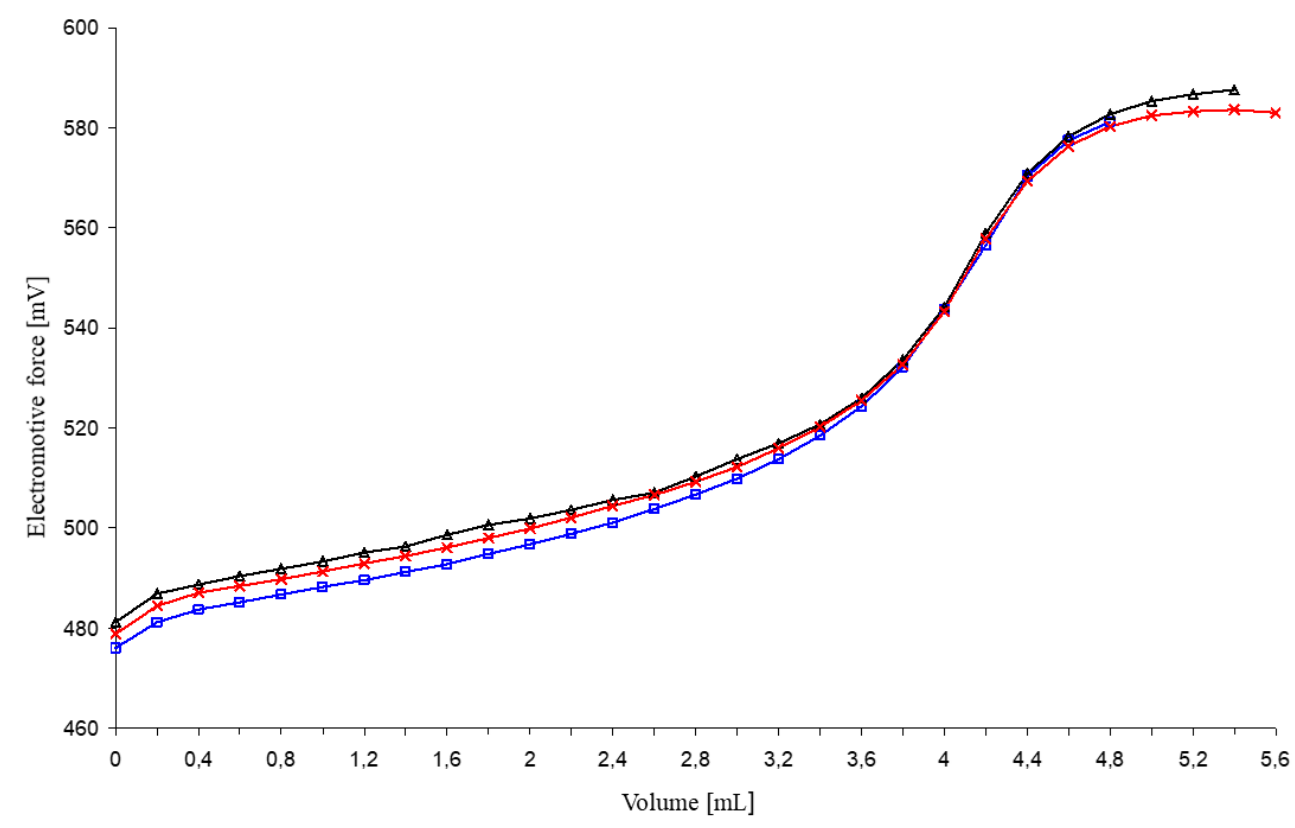

Figure 4. Examples of titration curves obtained for the same concentrations of standard chloride solutions

\subsubsection{Linearity}

To determine the linearity, 6 solutions at concentration in the range of $0.1 \mathrm{mmol} / \mathrm{L}-1 \mathrm{mmol} / \mathrm{L}$ were prepared. The results were analyzed using the linear regression method. The regression equation and the correlation coefficient were as follows: $\mathrm{y}[\mathrm{V}]=0.1372+1.9857 \times \mathrm{c} ; \mathrm{R}=0.9995$.

\subsubsection{Limit of detection and Limit of quantification}

Using standard deviation and slope of a straight line coefficient. The values of LOD and LOQ were determined and equal to $0.1 \mu \mathrm{g}$ and $0.32 \mu \mathrm{g}$ respectively.

\subsubsection{Specificity}

Due to the similar properties of chlorides to iodides and bromides and the possibility of their presence next to each other. their influence on the end point of titration was investigated. The graph below shows the titration curves obtained for chlorides next to iodides and bromides. The method can be considered specific, because the PK values are clearly separable - Fig. 5. 


\section{Analecta Technica Szegedinensia}

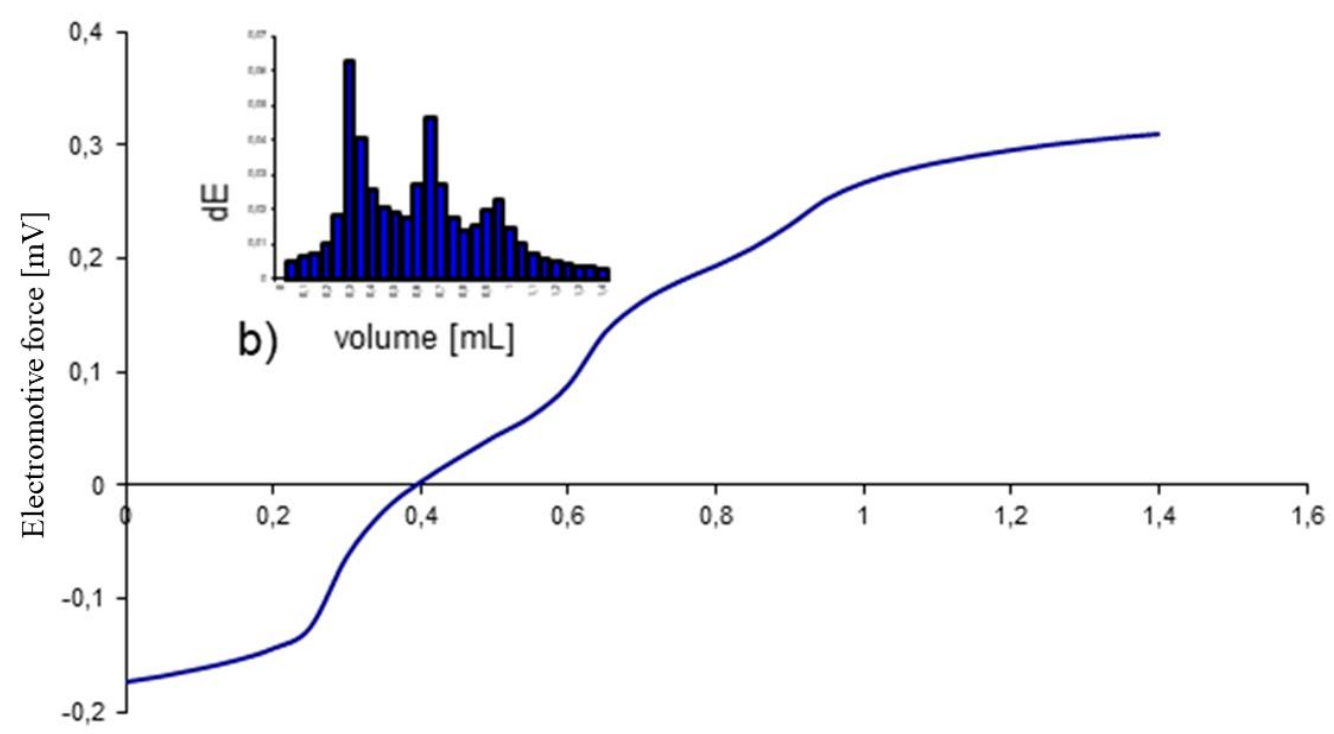

a)

Volume $[\mathrm{mL}]$

Figure 5. a) titration curve of chlorides in the presence of iodides and bromides; b) plot of the first derivative of the above determination

\subsubsection{Accuracy}

Recovery was calculated on the basis of determined content of verapamil hydrochloride to amount added to working solutions. The results are summarized in Tab. 2:

Table 2. The results of the recovery obtained for the Staveran ${ }^{\circledR}$ preparation and their statistical evaluation.

\begin{tabular}{|c|c|c|c|c|}
\hline sample & \% recovery & $\overline{\mathbf{x}}$ & SD & \%RSD \\
\hline 1 & 99.65 & & & \\
\hline 2 & 99.63 & & & \\
\hline 3 & 98.55 & \multirow{2}{*}{99.78} & \multirow{2}{*}{1.98} & \multirow{2}{*}{1.98} \\
\hline 4 & 103.68 & & & \\
\hline 5 & 98.59 & & & \\
\hline 6 & 98.60 & & \\
\hline
\end{tabular}

\subsection{Analysis of pharmaceutical preparations}

The pharmaceutical preparations of Verapamil ${ }^{\circledR}$ and Staveran $^{\circledR}$ in the form of tablets were analyzed. The manufacturer's declared content of verapamil hydrochloride in each tablet is $120 \mathrm{mg}$. The obtained results of chlorides content in the weighted portion of prepared samples enabled to determine the content of verapamil in samples under study - Tab. 3. In the next step, the calculated amounts were converted into the average content of the active substance under study per 1 tablet of the pharmaceutical preparation of Verapamil $^{\circledR}$ and Staveran ${ }^{\circledR}$ - Tab. 4. 


\section{Analecta Technica Szegedinensia}

Table 3. The content of verapamil hydrochloride determined in samples under study.

\begin{tabular}{|c|c|c|c|c|c|}
\hline $\begin{array}{c}\text { weighted } \\
\text { portion [mg] }\end{array}$ & $\begin{array}{c}\text { declared content } \\
{[\mathbf{m g}]}\end{array}$ & $\begin{array}{c}\text { determined } \\
\text { average amount } \\
{[\mathbf{m g}]}\end{array}$ & SD & \%RSD & n \\
\hline 613.2 & 309.0 & 315.8 & 12.8 & 4.06 & 6 \\
\hline 604.4 & 304.6 & 318.4 & 12.7 & 4.00 & 6 \\
\hline 605.3 & 305.0 & 318.2 & 9.6 & 3.00 & 6 \\
\hline 849.7 & 298.26 & 307.3 & 4.7 & 1.52 & 6 \\
\hline 850.7 & 298.61 & 311.1 & 5.2 & 1.66 & 6 \\
\hline 782.0 & 274.50 & 289.2 & 6.5 & 1.68 & 6 \\
\hline
\end{tabular}

Table 4. Calculated content of verapamil hydrochloride in preparations per 1 tablet of the pharmaceutical preparation Verapamil ${ }^{\circledR}$ and Staveran ${ }^{\circledR}$.

\begin{tabular}{|c|c|c|c|c|}
\hline $\begin{array}{c}\text { pharmaceutical } \\
\text { preparation }\end{array}$ & $\begin{array}{c}\text { average amount per } \\
\text { 1 tablet [mg] }\end{array}$ & SD & \% RSD & n \\
\hline Staveran $^{(8)} 120 \mathrm{mg}$ & 123.6 & 1.46 & 1.1 & 6 \\
\hline Verapamil $^{(\mathbb{2}} 120 \mathrm{mg}$ & 122.6 & 1.08 & 0.88 & 6 \\
\hline
\end{tabular}

\section{CONCLUSIONS}

Due to the obtained results, it can be concluded that the analytical method using the BO-05 microanalyzer is an effective and reliable in the indirect determination of verapamil in selected pharmaceutical preparations. Under conditions of experiment, the method featured high sensitivity, good precision and comparability of results as proven by the method validation and statistical analysis of the results. The presence of excipients in the formulation have no significant impact on the results. Due to the low cost and relatively short duration of the analysis as well as the significant automation. This method can be proposed as comparable to other methods of determining of drugs.

\section{REFERENCES}

[1] Al-Ghannam SM. 2006 A simple spectrophotometric method for the determination of $\beta$-blockers in dosage forms. Journal of Pharmaceutical and Biomedical Analysis 40(1). 151-156

[2] Liu J.-F. 2011 The impact of verapamil on catecholamine polymorphic ventricular tachycardia. Acta Cardiologica Sinica 27(2). 115-119

[3] Brogden RN. Benfield P. 1996 Verapamil: a review of its pharmacological properties and therapeutic use in coronary artery disease. Drugs. 51(5). 792-819. doi: 10.2165/00003495-199651050-00007.

[4] Singh BN. Ellrodt G. Peter CT. 1978 Verapamil: a review of its pharmacological properties and therapeutic use. Drugs. 15(3). 169-97. doi: 10.2165/00003495-197815030-00001.

[5] Pourkarim F. Rahimpour E. Jouyban A. 2019 Analytical techniques for the determination of verapamil in biological samples and dosage forms: An overview. Bioanalysis 11(23). 2189-2205

[6] Pourkarim F. Shayanfar A. Khoubnasabjafari M. et al. 2019 Determination of verapamil in exhaled breath condensate by using microextraction and liquid chromatography. Current Pharmaceutical Analysis 15(5). 535-541.

[7] Vijayabaskar S. Mahalingam V. Kalaivani. 2017 Analytical method development and validation for the analysis of verapamil hydrochloride and its related substances by using ultra performance liquid chromatography. Journal of Pharmaceutical and Biomedical Analysis 137. 189-195. 


\section{Analecta Technica Szegedinensia}

[8] Jhee OH. Hong JW. Om AS. Lee MH. Lee WS. Shaw LM. Lee JW. Kang JS. 2005 Direct determination of verapamil in rat plasma by coupled column microbore-HPLC method. Journal of Pharmaceutical and Biomedical Analysis 37 (2). 405-410.

[9] Walash M. Belal F. El-Enany N. Abdelsalam A. 2006 Spectrofluorometric determination of verapamil hydrochloride in pharmaceutical preparations and human plasma using organized media: Application to stability studies. Journal of AOAC International 89 (6). 1565-1572.

[10] Walash MI. Belal F. El-Enany N. Abdelal AA. 2009 Kinetic Spectrofluorometric Determination of Certain Calcium Channel Blockers via Oxidation with Cerium (IV) in Pharmaceutical Preparations. International Journal of Biomedical Science 5(2). 146-157.

[11] Kasim EA. Ghandour MA. El-Haty MT. Ahmed MM. 2003 Determination of verapamil by adsorptive stripping voltammetry in urine and pharmaceutical formulations. Journal of Pharmaceutical and Biomedical Analysis 30 (4). 921-929.

[12] Ortuño JA. Sánchez-Pedreño C. Gil A. 2005 Flow-injection pulse amperometric detection based on ion transfer across a water-plasticized polymeric membrane interface for the determination of verapamil. Analytica Chimica Acta 554 (1-2). 172-176. 